Report

\title{
Mitogenic properties of insulin-like growth factors I and II, insulin-like growth factor binding protein-3 and epidermal growth factor on human breast stromal cells in primary culture
}

\author{
Karen S. Strange, Darcy Wilkinson, Glenn Edin, and Joanne T. Emerman \\ Department of Anatomy, Faculty of Medicine, University of British Columbia Vancouver, BC, Canada
}

Key words: breast stromal cells, epidermal growth factor, insulin-like growth factors I and II, insulin-like growth factor binding protein 3 , primary culture

\begin{abstract}
Summary
Insulin-like growth factors I and II (IGF-I and IGF-II) are growth factors implicated in both normal mammary gland development and breast cancer. We have previously reported on the effects of components of the IGF system on breast epithelial cells. Since data suggests that stromal-epithelial interactions play a crucial role in breast cancer, we have now investigated the mitogenic properties of IGF-I, IGF-II, insulin-like growth factor binding protein-3 (IGFBP-3) and epidermal growth factor (EGF) on human breast stromal cells in primary culture. We show that, under serum-free conditions, stromal cells are stimulated to grow in response to IGF-I and IGF-II in a dose-dependent manner. IGF-I and EGF, a potent stimulator of human breast epithelial cell growth in primary culture and also associated with breast cancer, appear to stimulate stromal cell growth in a synergistic manner. IGFBP-3 does not inhibit the stimulation of growth by IGF-I, or IGF-I plus EGF. However, IGFBP-3 does inhibit the stimulation of growth by IGF-II. In contrast to our previous results with human breast epithelial cells, IGFBP-3 does not have an IGF-independent inhibitory effect on stromal cell growth. This study is the first to address the effects of IGF-I, IGF-II and IGFBP-3 alone and in combination with EGF on human breast stromal cell growth in primary culture. Characterizing the role of the IGF system in both normal breast epithelial cells and stromal cells will aid in our understanding of the mechanisms behind the role of the IGF system in breast cancer.
\end{abstract}

\section{Introduction}

Current statistics indicate that one in nine women will be diagnosed with breast cancer during her lifetime and that $\sim 50 \%$ of these women will die within 10 years of diagnosis. Although some progress has been made in the detection of early stage breast cancer and in the identification of important risk factors, as yet very little is understood about the cellular pathogenesis of this disease. We have developed a cell culture system in which we can routinely isolate and propagate human breast epithelial cells (HBEC) and stromal cells in primary culture [1]. Utilizing this culture system, we have previously reported the effects of insulin-like growth factors I and II (IGF-I, IGF-II), insulin-like growth factor binding protein-3
(IGFBP-3) and epidermal growth factor (EGF) on the epithelial cells. Since stromal-epithelial interactions are important in the normal breast development, we now report on the effects of components of the IGF system on the stromal cells.

Insulin-like growth factors (IGFs), classified as type I and type II, are polypeptides with structural homology to insulin. IGFs can elicit two types of biological responses: (1) rapid metabolic effects (insulinlike); and/or (2) slower growth promoting effects (mitogenic) [2]. Both IGF-I and IGF-II have been identified as potential risk factors for breast cancer. Recent population studies suggest an association between circulating IGF-I and breast cancer risk [3-5]. In a nested case-control study within the prospective Nurses' Health Study cohort, a positive correlation 
was observed between circulating IGF-I levels and breast cancer risk in premenopausal women [3]. A similar relationship was observed in two case-control studies $[4,5]$. In addition, there appears to be a relationship between (1) IGF-I gene expression and mammographic densities and (2) IGF-I serum levels and mammographic densities [6]. Mammographic density has been identified as a strong risk factor for breast cancer [7]. Stromal tissue, comprised of fibroblasts, adipocytes, extracellular matrix and vascular components, surrounds the epithelium. Both tissues are reflected on a mammogram as radiologic densities.

Messenger RNA analysis of breast cancer cell lines and in situ/immunohistochemical analysis of primary breast tumors suggest that IGF-I is produced by stromal cells and IGF-II is produced by both stromal and epithelial cells [8-14]. The bioactivity of IGFs is modulated by a number of components including: receptor activity, binding proteins, binding protein proteases, circulating levels and local production. IGFBP-3 is the major circulating IGF binding protein produced mainly in the liver; however, it is also produced locally by a number of tissues [15]. In a previous report [16], we observed that IGFBP-3 inhibits IGF-I and IGF-II stimulation of HBEC growth and also has IGF-independent growth inhibitory effects. This study was designed to examine the effects of IGF-I and IGF-II on breast stromal cell proliferation and the potential inhibitory effects of IGFB-3, both IGF-dependent and independent.

\section{Methods and materials}

Dissociation procedure. Breast tissue was obtained from reduction mammoplasties. The tissue was dissociated into single cells and epithelial organoids and frozen for future use. Breast tissue dissociation and cell culture protocols were as previously described [17]. Briefly, tissue samples were trimmed of fat, minced, and dissociated by shaking at $37^{\circ} \mathrm{C}$ for $\sim 18 \mathrm{~h}$ in a 1:1 mixture of Ham's F12:Dulbeco's modified Eagle's medium (F12:DME) supplemented with $10 \mathrm{mM}$ Hepes buffer $(\mathrm{H}), 2 \%$ bovine serum albumin (BSA), $300 \mathrm{U} / \mathrm{ml}$ collagenase and $100 \mathrm{U} / \mathrm{ml}$ hyaluronidase. Following dissociation, the resulting cell suspension was centrifuged several times, with washes, at $80 \times g$ for $4 \mathrm{~min}$, to remove the majority of epithelial cells and organoids. The remaining cells were pelleted by centrifugation at $100 \times g$ for $5 \mathrm{~min}$.
This stromal-cell enriched pellet was resuspended in DMSO-supplemented freezing medium and stored in liquid nitrogen until required.

Cell culture. Stromal cell pellets were thawed, washed and viable cells counted. The cells were resuspended in phenol red free DME/F12/H with $5 \%$ fetal calf serum and seeded at 16,000 cells per well in 96well tissue culture plates; $10^{6}$ cells were also placed in a $25 \mathrm{~cm}^{2}$ tissue culture flask. After $2 \mathrm{~h}$ incubation at $37^{\circ} \mathrm{C}$ in $5 \% \mathrm{CO}_{2}$ to allow attachment of fibroblasts, the growth medium was removed, the attached cells gently rinsed, and fresh growth medium added to the wells and flask. After $24 \mathrm{~h}$ incubation, the medium was replaced with a serum-free medium consisting of phenol red free DME/F12/H, $1 \mathrm{mg} / \mathrm{ml} \mathrm{BSA}, 1 \mathrm{ng} / \mathrm{ml}$ fibroblast growth factor, with or without the growth factors of interest (IGF-I, IGF-II, EGF, IGFBP-3). Thereafter, the medium was changed on alternate days. After 6 days, the cultures were terminated and growth determined by measuring optical densities using the tetrazolium dye (MTT) reduction assay [18].

Immunohistochemistry. The alkaline phosphatase anti-alkaline phosphatase (APAAP) procedure (DAKO EnVision system K4017) was used to stain cytospun cells harvested from the $25 \mathrm{~cm}^{2}$ tissue culture flasks at the time of the MTT assay. Primary antibodies used to identify these cells included those against vimentin (V9; Dako), cytokeratins (AE1/AE3, Dako), epithelial specific antigen (ESA; Vector) and Von Willibrand Factor 8 (Dako). Positive controls included sections of human breast tissue stained with these three antibodies; as a negative control, an anti-dextran monoclonal antibody was used with both tissue sections and cytospun cultured cell preparations.

MTT assay. Culture medium was removed and medium (phenol red free DME/F12/H) containing $1 \mathrm{mg} / \mathrm{ml}$ MTT (3[4,5-dimethylthiazol-2-yl]-2,5diphenyltetrazolium bromide; Sigma) was added to each well in a volume of $100 \mu 1$ and incubated in $5 \% \mathrm{CO}_{2}$ at $37^{\circ} \mathrm{C}$ for $5 \mathrm{~h}$. Afterwards, $100 \mu \mathrm{l}$ of $20 \%$ formol in saline was added to each well for $30 \mathrm{~min}$ at room temperature. The medium was removed and $100 \mu l$ of anhydrous isopropanol was added to each well for $1 \mathrm{~h}$ at room temperature. A 96-well microtiter plate reader (model EL 311, Biotek Instruments) was used to determine absorbance values at $540 \mathrm{~nm}$. 


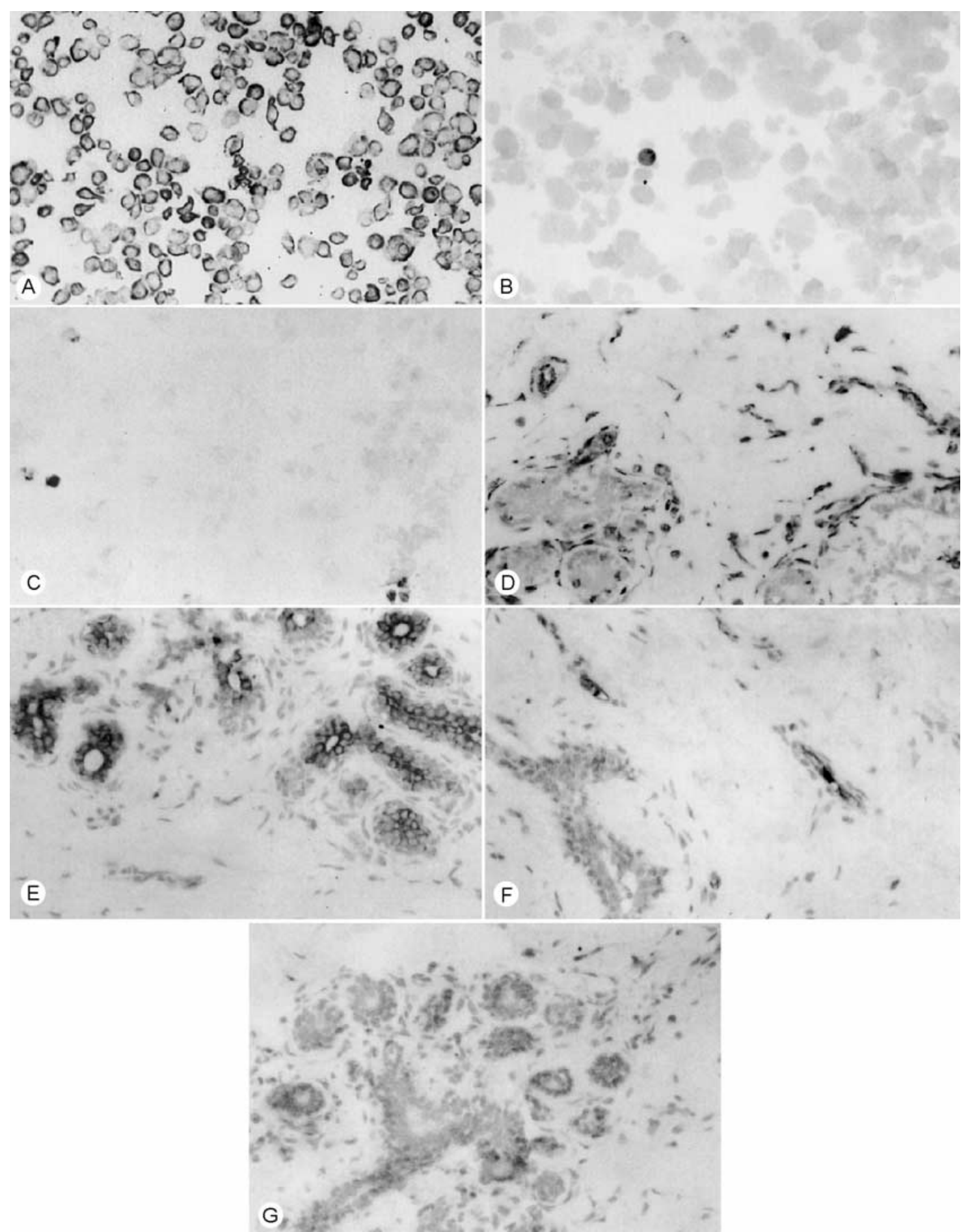

Figure 1. IHC staining of human breast stromal cells used in growth experiments. Cells cultured for 7 days in serum-free conditions (SF), cytospun and stained with antibodies to (A) vimentin, (B) cytokeratins (AE1/AE3) or (C) Factor 8. Very few keratin-positive (epithelial) or Factor 8-positive (endothelial) cells were detected. Positive staining of appropriate cells in human breast tissue with these three antibodies (vimentin, cytokeratins and factor 8) is shown (D), (E) and (F)). No staining was seen using an anti-dextran monoclonal antibody (negative control; (G)). 

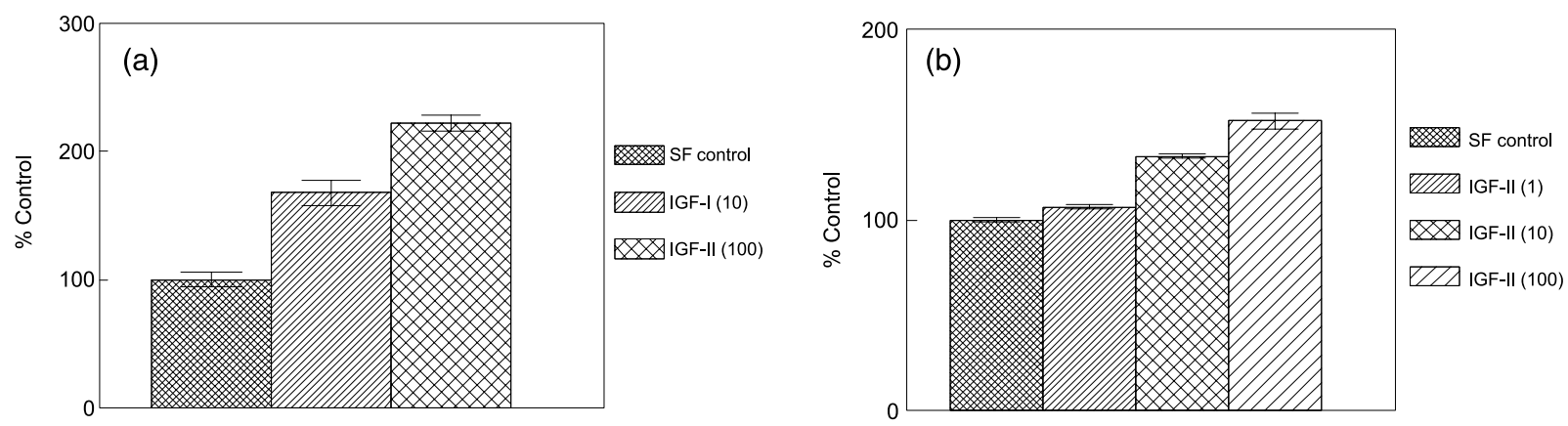

Figure 2. Effects of IGF-I and IGF-II on human breast stromal cell growth in primary culture. Human breast stromal cells were cultured in SF in the presence or absence of IGF-I $(10$ or $100 \mathrm{ng} / \mathrm{ml})$ or IGF-II $(1,10$ or $100 \mathrm{ng} / \mathrm{ml})$ for approximately 6 days. The MTT assay was used to assess cell growth. Results are expressed as a percentage of the control condition (SF condition). (a) IGF-I (10 or $100 \mathrm{ng} / \mathrm{ml})$ significantly stimulated cell growth above control levels ( $p<0.05 ; n=5$ ). Similarly, (b) shows that IGF-II (10 or $100 \mathrm{ng} / \mathrm{ml})$ significantly stimulated cell growth above control levels $(p<0.05 ; n=3)$.

Optical densities were converted to a percentage of control (cultures incubated in medium without any growth factors).

Statistical analysis. An ANOVA test was performed on all growth experiments. For post-hoc analysis a Tukey's test was utilized.

\section{Results}

\section{Isolation and propagation of human breast stromal cells}

We collected tissue from reduction mammoplasties and performed enzymatic and mechanical dissociation which resulted in a mixed cell population of epithelial and stromal cells (see Methods and materials). This mixed cell population was subjected to differential centrifugation and differential attachment to tissue culture plastic in order to separate the epithelial and stromal cell components. The stromal cell component was then used for the experiments outlined in this report. In order to ensure that the majority of cells we were culturing were stromal cells (as opposed to epithelial cells), cytospun preparations of cultured cells were stained using antibodies against epithelial and stromal markers: cytokeratins (AE1/AE3), ESA, vimentin (V9), and Von Willibrand Factor 8 (present in endothelial cells). The vast majority of cells cultured were cytokeratin-, ESA- and Factor 8-negative and vimentin positive (Figure 1). As well, microscopic morphology of the cells in culture was fibroblastic.

\section{Stimulation of breast stromal cell growth in primary culture by IGF-I and IGF-II}

Human breast stromal cells were cultured in serumfree conditions to examine the effects of IGF-I and IGF-II at two concentrations: 10 and $100 \mathrm{ng} / \mathrm{ml}$. Cultures were maintained for 6 days. At the end of the culture period an MTT assay was performed. Figure 2(a) and (b) are representative graphs demonstrating that both IGF-I and IGF-II stimulate growth in a dose-dependent manner $(p<0.05 ; n=5)$.

\section{IGFBP-3 inhibition of growth stimulation of HBEC by IGF-I or IGF-II}

IGFBP-3 is the major circulating IGF binding protein, which is also produced locally in tissues. We examined the effects of recombinant IGFBP-3 $(5-500 \mathrm{ng} / \mathrm{ml})$ on the growth of human breast stromal cells in primary culture in the presence of IGF-I or IGF-II (10 and $100 \mathrm{ng} / \mathrm{ml}$ ). Both IGFBP-3 and IGF-I or IGF-II were added simultaneously to the culture medium. Cultures were maintained for 6 days. At the end of the culture period an MTT assay was performed. IGFBP-3 did not inhibit growth stimulation by IGF-I $(p<0.05$; $n=6$; Figure 3(a)). However, it does inhibit growth stimulation by IGF-II ( $p<0.05 ; n=3$; Figure 3(b)).

\section{IGF-independent effects on growth of human breast stromal cells by IGFBP-3}

In a previous report [16], we demonstrated that IGFBP-3 inhibited human breast epithelial cell growth independent of IGF-I. We examined these effects on breast stromal cells in primary culture. We grew human breast stromal cells in primary culture in the 

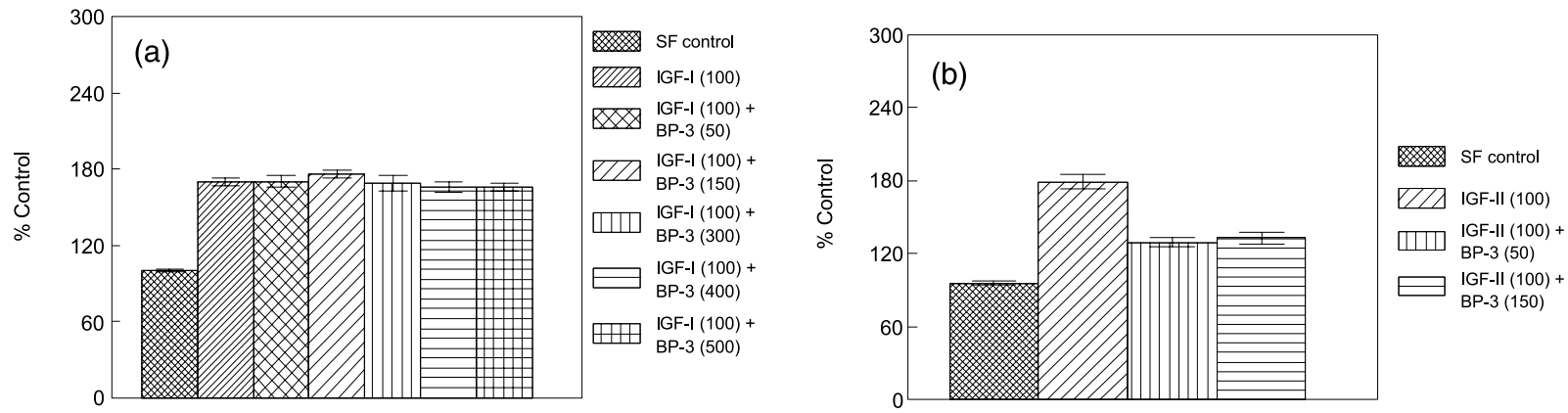

Figure 3. Effects of IGFBP-3 on IGF-I and IGF-II stimulation of human breast stromal cell growth in primary culture. Human breast stromal cells were cultured in serum-free conditions (SF) in the presence of IGF-I (10 or $100 \mathrm{ng} / \mathrm{ml})$ or IGF-II $(100 \mathrm{ng} / \mathrm{ml})$ with or without IGFBP-3 $(50-500 \mathrm{ng} / \mathrm{ml})$ for approximately 6 days. IGF-I or IGF-II and IGFBP-3 were added to the culture medium at the same time. The MTT assay was used to assess cell growth. Results are expressed as a percentage of the control condition (SF condition). IGFBP-3 did not inhibit IGF-I stimulated cell growth $(n=6$; (a)); in contrast, IGFBP-3 did inhibit IGF-II stimulated cell growth $(p<0.05 ; n=3$; (b)).

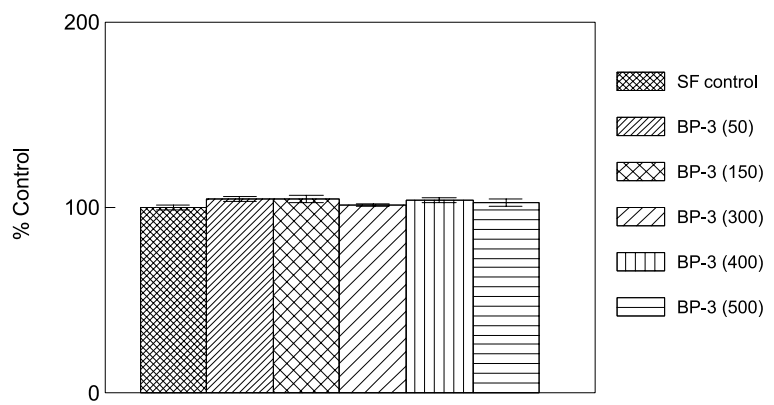

Figure 4. IGF-independent effects of IGFBP-3 on human breast stromal cell growth in primary culture. Human breast stromal cells were cultured in serum-free conditions in the presence or absence of IGFBP-3 (50-500 ng/ml) for approximately 6 days. The MTT assay was used to assess cell growth. Results are expressed as a percentage of the control condition (SF condition). IGFBP-3 alone did not inhibit cell growth $(n=6)$.

presence and absence of IGFBP-3. Cultures were maintained for 6 days. At the end of the culture period an MTT assay was performed. Figure 4 demonstrates that IGFBP-3 does not demonstrate IGFindependent inhibition of growth in serum-free conditions $(p<0.05 ; n=6)$.

\section{Stimulation of human breast stromal cell growth by IGF-I and EGF}

We examined the growth of human breast stromal cells in primary culture in the presence of IGF-I and EGF, alone and in combination. We grew human breast stromal cells under serum-free conditions in the presence of either (a) IGF-I alone $(10 \mathrm{ng} / \mathrm{ml})$, or (b) EGF alone $(1$ or $10 \mathrm{ng} / \mathrm{ml})$ or $(\mathrm{c})$ IGF-I $(10 \mathrm{ng} / \mathrm{ml})$ plus EGF ( 1 or $10 \mathrm{ng} / \mathrm{ml}$ ). Cultures were maintained for 6 days. At the end of the culture period an MTT assay was performed. Figure 5 demonstrates that IGF-I $(10 \mathrm{ng} / \mathrm{ml})$

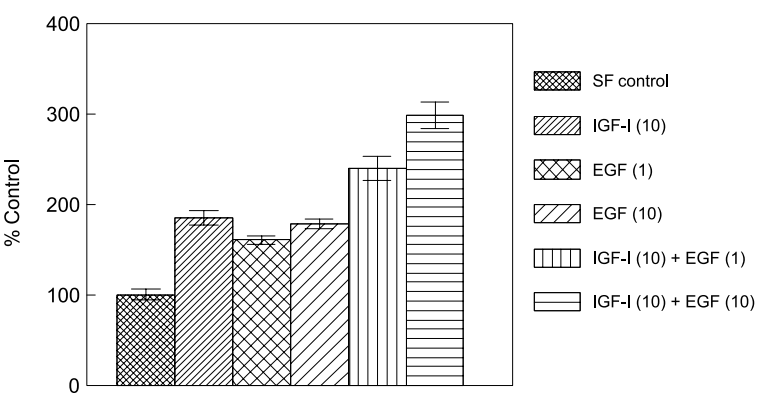

Figure 5. Effects of IGF-I and EGF on human breast stromal cell growth in primary culture. Human breast stromal cells were cultured in serum-free conditions (SF) in the presence of either (a) IGF-I alone $(10 \mathrm{ng} / \mathrm{ml})$, or (b) EGF alone $(1$ or $10 \mathrm{ng} / \mathrm{ml})$ or (c) IGF-I $(10 \mathrm{ng} / \mathrm{ml})$ plus EGF ( 1 or $10 \mathrm{ng} / \mathrm{ml}$ ) for approximately 6 days. The MTT assay was used to assess cell growth. Results are expressed as a percentage of the control condition (SF condition). IGF $(10 \mathrm{ng} / \mathrm{ml})$ alone and EGF (1 or $10 \mathrm{ng} / \mathrm{ml}$ ) alone significantly stimulated cell growth above control levels $(p<0.05 ; n=6)$. IGF $(10 \mathrm{ng} / \mathrm{ml})$ plus EGF (1 or $10 \mathrm{ng} / \mathrm{ml}$ ) significantly stimulated cell growth above control levels and above either growth factor alone $(p<0.05$; $n=6)$.

plus EGF (1 or $10 \mathrm{ng} / \mathrm{ml}$ ) stimulates human breast stromal cell growth greater than either growth factor alone $(p<0.05 ; n=6)$.

\section{Inhibitory effects of IGFBP-3 on human breast stromal cell growth in the presence of IGF-I and EGF}

We examined the effects of recombinant IGFBP$3(50,150 \mathrm{ng} / \mathrm{ml})$ on the growth of human breast stromal cells in primary culture in the presence of IGF-I $(10 \mathrm{ng} / \mathrm{ml})$ and EGF $(10 \mathrm{ng} / \mathrm{ml})$. Both IGFBP3 and the growth factors were added simultaneously to the culture medium. Cultures were maintained for 6 days. At the end of the culture period an MTT 


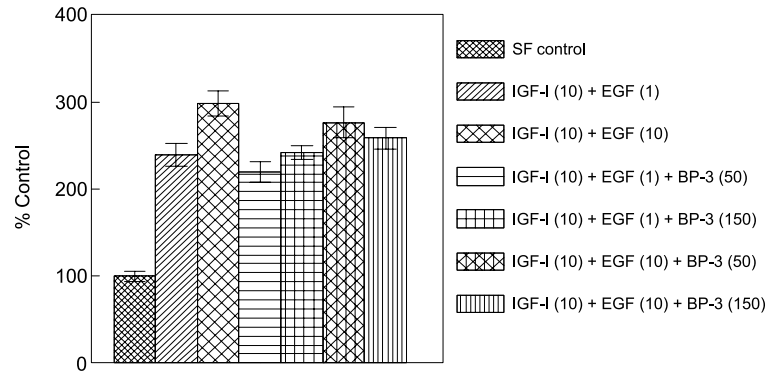

Figure 6. Effects of IGFBP-3 on IGF-I and EGF stimulation of human breast stromal cell growth in primary culture. Human breast stromal cells were cultured in serum-free conditions (SF) in the presence of IGF-I $(10 \mathrm{ng} / \mathrm{ml})$ and/or EGF (1 or $10 \mathrm{ng} / \mathrm{ml})$ with or without IGFBP-3 (50 or $150 \mathrm{ng} / \mathrm{ml}$ ) for approximately 6 days. The MTT assay was used to assess cell growth. Results are expressed as a percentage of the control condition (SF condition). IGFBP-3 (50 or $150 \mathrm{ng} / \mathrm{ml}$ ) did not inhibit the stimulatory effects of IGF-I $(10 \mathrm{ng} / \mathrm{ml})$ plus EGF $(1$ or $10 \mathrm{ng} / \mathrm{ml})(n=3)$.

assay was performed. IGFBP-3 did not inhibit stimulation of stromal cell growth by IGF-I and EGF $(n=3$; Figure 6).

\section{IGF-independent effects of IGFBP-3 on human breast stromal cells in the presence of EGF}

We examined the IGF-independent effects of IGFBP-3 on human breast stromal cells in primary culture in the presence of EGF. We grew human breast stromal cells in serum-free conditions in the presence of IGFBP-3 $(50,150,400,500 \mathrm{ng} / \mathrm{ml})$ and EGF $(10 \mathrm{ng} / \mathrm{ml})$. Both IGFBP-3 and EGF were added simultaneously to the culture medium. Cultures were maintained for 6 days. At the end of the culture period an MTT assay was performed. Figure 7 demonstrates that IGFBP-3 had

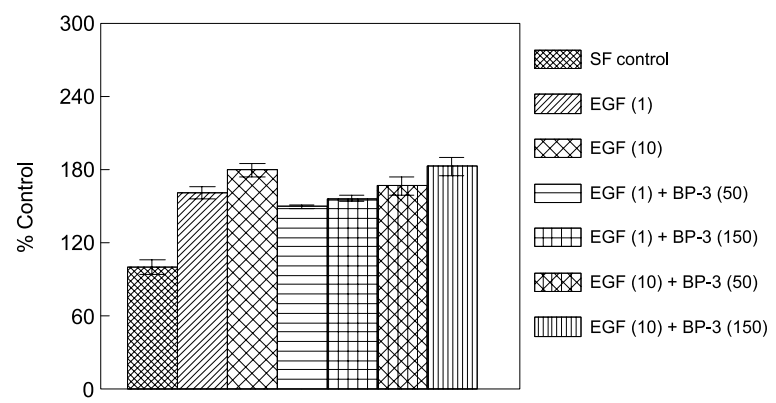

Figure 7. Effects of IGFBP-3 on EGF stimulation of human breast stromal cell growth in primary culture. Human breast stromal cells were cultured in serum-free conditions (SF) in the presence of EGF $(1$ or $10 \mathrm{ng} / \mathrm{ml})$ with or without IGFBP-3 $(50,150 \mathrm{ng} / \mathrm{ml})$ for approximately 6 days. The MTT assay was used to assess cell growth. Results are expressed as a percentage of the control condition (SF condition). IGFBP-3 did not inhibit the stimulation of human breast stromal cell growth by $\mathrm{EGF}(n=4)$. no effect on cell growth in human breast stromal cells with EGF present in the culture media $(n=4)$.

\section{Discussion}

In this study, we examined the effects of IGF-I, IGFII, IGFBP-3 and EGF on human breast stromal cells in primary culture. We demonstrate that (a) IGF-I and IGF-II stimulate human breast stromal cells in a dose-dependent manner; (b) IGF-I and EGF added to the culture medium together stimulate human breast stromal cell growth in an additive manner; (c) IGFBP3 does not inhibit the stimulatory effects of IGF-I and IGF-I plus EGF in human breast stromal cells; however, IGFBP-3 does inhibit IGF-II stimulation of human breast stromal cells; and (d) unlike our observations in human breast epithelial cells, IGFBP-3 does not inhibit the growth of human breast stromal cells in an IGF-independent manner.

Using our culture system, we routinely propagate human breast stromal cells in primary culture. We have confirmed the stromal (non-epithelial) nature of the cultured cells by staining with antibodies to cytokeratins, vimentin and Von Willibrand Factor 8. To our knowledge, this is the first report examining the mitogenic effects of IGF-I, IGF-II, and IGFBP-3 alone and in combination with EGF on human breast stromal cells in primary culture.

In population studies, circulating IGF-I has been identified as a potential breast cancer risk factor [3-5]. In addition, there appears to be a correlation between IGF-I gene expression and IGF-I serum levels with mammographic densities [6]. There is now evidence of a relationship between mammographic density and breast cancer [7]. Our results show a direct interaction between IGF-I or IGF-II and normal human breast stromal cells. In a previous paper [16] we reported that IGF-I and IGF-II stimulated growth of epithelial cells. Therefore, IGFs can stimulate growth of both epithelial and stromal cells. Since stromal-epithelial interactions are implicated in tumor development as well as normal breast development, our demonstration that IGF-I and IGF-II have direct effects on the stromal cells as well as the epithelial cells, serves as a baseline for future examination of breast neoplasms.

Interestingly, we demonstrated that IGFBP-3, a protein known to inhibit IGF-I and IGF-II stimulation in epithelial cells, does not have any effect on IGFI stimulation in stromal cells. It does however inhibit IGF-II stimulation. In addition, we have demonstrated 
that IGFBP-3 does not inhibit stimulation of stromal cells by IGF-I + EGF. This is in contrast to the effect observed in epithelial cells [16]. This suggests that there are different mechanisms involved in (a) the interaction between IGFBP-3 and epithelial cells and that between IGFBP-3 and stromal cells, and (b) the interaction between IGFBP-3 and IGF-I and that between IGFBP-3 and IGF-II.

We have previously reported that IGFBP-3 has IGF-independent effects in human breast epithelial cells [16]. We and others have reported similar effects on breast cancer cell lines including MCF-7 and Hs578T $[16,19,20]$. In this study we examined the effects of IGFBP-3 on human breast stromal cell growth in primary culture in the absence of IGF-I and IGF-II. In contrast to data on epithelial cells, IGF-independent IGFBP-3 does not inhibit cell growth in the stromal cells. In addition, we demonstrated that, when EGF and IGFBP-3 is simultaneously added to the culture medium, IGFBP-3 does not inhibit cell growth. This is in contrast to effects observed in epithelial cells where IGFBP-3 inhibits EGF stimulation of epithelial cells [16]. Again, these results suggests that IGFBP-3 may exert its effects via different mechanisms in epithelial cells and stromal cells.

This study has been the first to address the effects of IGF-I, IGF-II and IGFBP-3 alone and in combination with EGF on human breast stromal cell growth in primary culture. Given the fact that stromal-epithelial interactions are important in tumor development [21], it is important to characterize the role of the IGF system, both growth factors and binding proteins, in normal breast stromal cells as well as epithelial cells.

\section{Acknowledgements}

The authors would like to thank Dr M.J. Sproul, Dr R. Warren, Dr P. Clugston and Dr P. Lennox for supplying breast tissue from reduction mammoplasties. A Canadian Breast Cancer Research Initiative Streams of Excellence Grant funds this work.

\section{References}

1. Emerman JT, Wilkinson DA: Routine culturing of normal, dysplastic and malignant human mammary epithelial cells from small tissue samples. In Vitro Cell Dev Biol 26: 1186-1194, 1990

2. Krywicki RF, Yee DR: The insulin-like growth factor family of ligands, receptors and binding proteins. Br Cancer Res Treat 22: 7-19, 1992
3. Hankinson SE, Willett WC, Colditz GA, Hunter DJ, Michaud DS, Deroo B, Rosner B, Speizer FE, Pollak M: Circulating concentrations of insulin-like growth factor-I and risk of breast cancer. Lancet 351: 1393-1396, 1998

4. Peyrat JP, Bonneterre J, Hecquet B, Vennin P, Louchez MM, Fournier C, Lefebvre J, Demaille A: Plasma insulin-like growth factor-I (IGF-I) concentrations in human breast cancer. Eur J Cancer 29A: 492-497, 1993

5. Bruning PF, Van Doorn J, Bonfrer JM, Van Noord PA, Korse CM, Linders TC, Hart AA: Insulin-like growth factor-binding protein 3 is decreased in early-stage operable premenopausal breast cancer. Int J Cancer 62: 266-270, 1995

6. Byrne C, Colditz GA, Willett WC, Speizer FE, Pollak M, Hankinson SE: Plasma insulin-like growth factor (IGF) I, IGFbinding protein 3 and mammographic density. Cancer Res 60: 3744-3748, 2000

7. Boyd N, Lockwood G, Byng J, Tritchler DL, Yaffe MJ: Mammographic densities and breast cancer risk. Cancer Epidemiol Biomarkers Prev 7: 1133-1144, 1998

8. Yee D, Paik S, Lebovic GS, Marcus RR, Favoni RE, Cullen KJ, Lippman ME, Rosen N: Analysis of IGF-I gene expression in malignancy, evidence for a paracrine role in human breast cancer. Mol Endocrinol 3: 509-517, 1989

9. Ahmed SR, Manni A, Gray G, Hammond JM: Characterization and hormonal regulation of radioimmunoassayable IGF-I (insulin-like growth factor I) like activity and IGF-binding proteins secreted by human breast cancer cells. Anticancer Res 10: 1217-1224, 1990

10. Yee D, Cullen KJ, Paik S, Perdue JF, Hampton B, Schwartz A, Lippman ME, Rosen N: Insulin-like growth factor II mRNA expression in human breast cancer. Cancer Res 48: 6691-6696, 1988

11. Paik S: Expression of IGF-I and IGF-II mRNA in breast tissue. Breast Cancer Res Treat 22: 31-38, 1992

12. Giani C, Cullen KJ, Campani D, Rasmussen A: IGF-II mRNA and protein are expressed in the stroma of invasive breast cancers: an in situ hybridization and immunohistochemistry study. Breast Cancer Res Treat 41: 43-50, 1996

13. Cullen K, Yee D, Sly W, Perdue J, Hampton B, Lippman $\mathrm{M}$, Rosen N: Insulin-like growth factor receptor expression and function in human breast cancer. Cancer Res 50: 48-53, 1990

14. Singer C, Rasmussen A, Smith HS, Lippman ME, Lynch T, Cullen KJ: Malignant breast epithelium selects for insulinlike growth factor II expression breast stroma: evidence for paracrine function. Cancer Res 55: 2448-2454, 1995

15. Jones J, Clemmons D: Insulin-like growth factors and their binding proteins: biological actions. Endocr Rev 16: 3-34, 1995

16. Strange KS, Wilkinson D, Emerman JT: Mitogenic properties of insulin-like growth factors I and II, insulin-like growth factor binding protein-3 and epidermal growth factor on human breast epithelial cells in primary culture. Breast Cancer Res Treat 75: 203-212, 2002

17. Stingl J, Eaves CJ, Emerman JT: Characterization of normal human breast epithelial cell subpopulations isolated by fluorescence-activated cell sorting and their clonogenic growth in vitro. In: Ip MM, Asch BB (eds) Methods in Mammary Gland Biology and Breast Cancer Research. 2000, pp 177-193

18. Landegren U: Measurement of cell numbers by means of the endogenous enzyme hexosaminidase. Applications to detection of lymphokines and cell surface antigens. J Immunol Meth 67: 379-388, 1984 
19. Nickerson T, Huynh H, Pollak M: Insulin-like growth factor binding protein 3 induces apoptosis in MCF7 breast cancer cells. Biochem Biophys Res Commun 237: 690-693, 1997

20. Oh Y, Muller HL, Lamson G, Rosenfeld RG: Insulin-like growth factor (IGF)-binding protein-3 in Hs578T human breast cancer cells. J Biol Chem 268: 14964-14971, 1993

21. Imagawa W, Pedchenko VK, Helber J, Zhang H: Hormone/growth factor interactions mediating epithelial/stromal communication in mammary gland development and carcinogenesis. J Steroid Biochem Mol Biol 80: 213-230, 2002

Address for offprints and correspondence: Dr Joanne T. Emerman, Department of Anatomy, Faculty of Medicine, University of British Columbia, 2177 Wesbrook Mall, Vancouver, BC, Canada V6T 1Z3; Tel.: +1-604-822-2969; Fax: +1-604-822-2316; E-mail: jemerman@interchange.ubc.ca 